\title{
III. COMPETITION
}

\section{A. Article 81(1)}

The period under review (Autumn 1999-Spring 2001) saw a number of important cases decided by the Court of Justice involving breaches of Article 81(1). Pre-eminent are three judgments involving cartels and one involving distribution contracts.

\section{Solvay and ICI}

The detritus still remaining from the shambles that was Commission administrative procedure in the late 1980s has been cleared away, but only temporarily, in two appeal judgments of the Court of Justice. In 1990 Solvay and ICI were libelled by the Commission with infringements of both Articles 81 and 82 in the market for soda ash, used in the manufacture of glass, and heavily fined ( $€ 23$ million and $€ 10$ million respectively). ${ }^{1}$ Having waited upon the annulment in 1994 of the notorious $P V C$ decision by the Court of Justice for gross procedural flaws in its adoption, ${ }^{2}$ the Court of First Instance followed suit and annulled all decisions addressed to Solvay and to ICI for the same reason. ${ }^{3}$ The Commission appealed, and the appeals were dismissed (finally) in April 2000. ${ }^{4}$ However in December 2000 the Commission re-adopted the offending decisions, simply recycling measures and procedures preparatory to the original decisions but this time complying with proper form in the final adoption; ${ }^{5}$ the fines remain unchanged. This, it may be recalled from a previous note, ${ }^{6}$ is a légèrdemain deployed once before by the Commission in re-adopting the $P V C$ decision, and it passed muster with the Court of First Instance. ${ }^{7}$ An appeal in that case is still pending, ${ }^{8}$ but it is submitted that the Court of Justice will not be impressed by the procedural liberties taken by the Commission. In terms of prescription alone it would be particularly abusive for Solvay and ICI in which case, remember, the Commission has adopted decisions in December 2000 condemning (alleged) infringements of the competition rules which occurred in the 1980s.

\section{Cartonboard}

In 1994 the Commission found a cartel amongst one trade association and 18 producers (half of them in EFTA Member States) of cartonboard and imposed

\footnotetext{
1. Decisions 91/297-300 OJ 1991 L152/1, 16, 21, 40.

2. Case C-137/92P Commission v. BASF and ors [1994] E.C.R. I-2555.

3. Cases T-30 etc/91 Solvay \& ICI v. Commission [1995] E.C.R. II-1775, 1821, 1825, 1847, 1901.

4. Case C-286/95P Commission v. ICI and Cases C-287 \& 288/95P Commission v. Solvay, judgments of 6 April 2000, not yet reported.

5. Solvay, Solvay and ICI, decisions adopted 13 Dec. 2000, not yet published.

6. 49 I.C.L.Q. $227,228$.

7. Cases T-305 etc/94 Limburgse Vinyl Maatschappij and ors v. Commission [1999]

E.C.R. II-931.

8. Case C238/99P Limburgse Vinyl Maatschappij and ors v. Commission, pending.
} 
fines of just over $€ 131$ million. ${ }^{9}$ Sixteen of them challenged the decision under Article 230. In 1998 the Court of First Instance annulled various minor details of the decision for a number of the applicants but generally sustained the Commission; ${ }^{10}$ total fines were reduced by only $€ 11$ million. Ten appealed to the Court of Justice, which in a (relatively speedy) series of judgments decided the appeals in November $2000 .^{11}$

Generally there were no surprises, the Court of Justice for the most part upholding the Court of First Instance. But one interesting development is the Court's dicta on the quantum of fines imposed. The Court enjoys unlimited jurisdiction to cancel, reduce or increase Commission fines, ${ }^{12}$ and it is bound to consider whether the amount is proportionate to the gravity and duration of the infraction, taking into account all relevant factors of the case. ${ }^{13}$ In 1998 the Commission issued a notice detailing various tariffs it uses in the calculation of a fine, ${ }^{14}$ but when pleaded by a number of the Cartonboard appellants the Court of First Instance was disinclined to take notice of it. ${ }^{15}$ A number of the appeals were based therefore upon the ground that the Court of First Instance had erred in accepting the Commission's reasoning on the fixing of fines. In fact two of the appeals succeeded in part owing to material flaws in the Commission's arithmetic which went insufficiently attended by the Court of First Instance. ${ }^{16}$ Otherwise the Court of Justice recognised the legitimate discretion enjoyed by the Commission, but laid down a marker that it ought to adopt greater precision in its computation:

[T] he essential procedural requirement to state reasons is satisfied where the Commission indicates in its decision the factors which enabled it to determine the gravity of the infringement and its duration ....

However, it may in its decision give reasons going beyond [those] requirements .... It may indeed be desirable for the Commission to make use of that possibility in order to enable undertakings to acquire a detailed knowledge of the method of calculating the fine imposed on them. More generally, such a course of action may serve to render the administrative act more transparent and facilitate the exercise by the Court of First Instance of its unlimited jurisdiction, which enables it to review not only the legality of the contested decision but also the appropriateness of the fine imposed. ${ }^{17}$

Prudence dictates keeping a weather eye on how this obligation develops and hardens.

9. Decision 94/601 (Cartonboard) OJ 1994 L243/1.

10. In a series of judgments the first of which is Case T-295/94 Buchmann v. Commission [1998] E.C.R. II-813.

11. In a series of judgments the first of which is Case C-248/98P Koninklijke KNP BT v. Commission, judgments of 16 Nov. 2000, not yet reported.

12. EC Treaty, Art. 229; Regulation 17/62, JO 1962, 204, Art. 17.

13. Case T-49/95 van Megen Sports v. Commission [1996] E.C.R. II-1799.

14. Guidelines on the method of setting fines pursuant to Art. 15(2) of Regulation No. 17 and Art. 65(5) of the ECSC Treaty, OJ 1998 C9/3.

15. Case T-294/94 Buchmann, supra n.10 at 862; Case T-334/94 Sarrió v. Commission [1998] E.C.R. II-1439 at 1541.

16. Case C-280/98P Moritz J. Weig v. Commission and Case C-291/98P Sarrió v. Commission, judgments of 16 Nov. 2000, not yet reported.

17. Case C-280/98P Moritz J. Weig, Ibid at paras 43, 46, 47. 


\section{Cement}

The Commission adopted three major cartel decisions in 1994, Cartonboard, Steel Beams $^{18}$ and Cement. ${ }^{19}$ Cartonboard is discussed above, Steel Beams was decided by the Court of First Instance, which generally sustained the Commission, in $1999,{ }^{20}$ and in March 2000 the Court of First Instance delivered its judgment in Cement. ${ }^{21}$ It is easily the lengthiest judgment ever handed down by the Court, clocking up a whopping 5134 paragraphs; the dispositif alone runs to ten and a half pages in the Official Journal. ${ }^{22}$ It remains a moot point whether it will be published in full in the E.C.R. and, if it is, whether anyone will ever read it.

The judgment is a review of a decision in which the Commission found a pan-European cartel in the markets for grey cement, white cement and the clinker which is used in the production of both. The cartel was prosecuted through a series of agreements and concerted practices (although constituting a single continuous infraction of Article 81(1)) with the purpose of market sharing, primarily the protection of producers' home markets, although there were also elements of price fixing. The Commission identified the federation of the European cement industry (Cembureau), eight national associations and 33 individual producers (three of them, one Swiss, one Norwegian and one Swedish, EFTA producers) as parties to the cartel, and imposed fines totalling $€ 248$ million. All but one of the addressees of the decision raised annulment proceedings under Article 230.

The most important aspect of the judgment is what the Court had to say about rights of defence, and in particular access to the Commission investigation file. The statement of objections must provide all information necessary for an undertaking to be able properly to defend itself against the charge; this is a procedural guarantee intended to protect the rights of defence and forms a fundamental principle of Community law. ${ }^{23}$ In addition, the Commission is under a duty to make available to undertakings the subject of investigation the entire file save for documents containing business secrets of other undertakings, other confidential information and internal Commission documents. ${ }^{24}$ Whilst failure to discharge this duty does not lead automatically to annulment of a decision, the rights of defence are infringed if there is "any even a small chance" the outcome of the administrative procedure might otherwise have been different ${ }^{25}$ — which was found to be the case for three of the appellants. ${ }^{26}$ This principle applies also to documents in the Commission's possession which do not form part of the file but which undertakings under investigation have requested to examine, which request was refused. ${ }^{27}$ However, the Commission need provide no translation of supporting documents, ${ }^{28}$ and even if it sends documents which are integral to the

18. Decision $94 / 215$ OJ 1994 L116/1.

19. Decision 94/815 OJ 1994 L343/1.

20. Case T-141/94 Thyssen Stahl v. Commission [1999] E.C.R. II-343; under appeal as Case C-194/99P Thyssen Stahl v. Commission, pending.

21. Cases T-25 etc/95 Cimenteries CBR and ors v. Commission, judgment of 15 March 2000 , not yet reported.

22. OJ $2000 \mathrm{C} 122 / 18$.

23. Cement judgment, supra n.21, para. 142.

24. Paras $142-144$.

25. Paras 241, 247.

26. Cases T-38, $52 \& 56 / 95$.

27. Cement judgment, supra n.21, para. 383.

28. Paras 631, 633, 635. 
decision in a language other than that of the Member State in which an undertaking is domiciled-this being a requirement of Regulation $1^{29}$-it is an irregularity which, "however regrettable", vitiates the administrative procedure only if harmful consequences can be shown..$^{30}$

In the event, the Court sustained the Commission but only in part. Nine of the 41 appellants $^{31}$ succeeded entirely because the Commission had failed to adduce evidence to support their participation in the cartel. Most of the others succeeded in part because of a general miscalculation by the Commission of duration of the infringement. And whilst the imprecision of the statement of objections and the original refusal to allow proper access to the file had been put right during the administrative proceedings (after it being ordered by the Court), the Commission was as a result ordered to pay a substantial portion of the costs. Fines overall were more than halved, to $€ 110$ million.

The judgment has now been appealed by a number of still disgruntled appellants. ${ }^{32}$ The appeals will hopefully require less stamina from the Court of Justice than that of the Court of First Instance. But there is already one footnote to the judgment: in two of the cases in which the Court of First Instance had annulled the decision ${ }^{33}$ the Commission repaid the fines but refused to pay interest thereon. This refusal has now been challenged by the two aggrieved undertakings in question. ${ }^{34}$

\section{Bayer}

It may be recalled from a previous note ${ }^{35}$ that in 1996 the Commission found the pharmaceutical producer Bayer to have imposed an export ban upon its Spanish and French buyers of adalat, a calcium antagonist used in the treatment of cardiovascular diseases, the ban effected by means of identification of exporting (to the dearer U.K. market) wholesalers and reduction of supplies to them. This, said the Commission, was an "agreement" within the meaning of Article 81(1), even thought the wholesalers had fought tenaciously against it, and fined Bayer $€ 3$ million. ${ }^{36}$ If the Commission were right, it would extend significantly the meaning of the term "agreement" and limit contractual freedom appreciably. Five years on we now learn from the Court of First Instance that the Commission was wrong. ${ }^{37}$ In a limitation (against the grain?) to the application of Article 81(1), the Court said:

[I]n accordance with the general scheme of the Treaty, an undertaking may be penalised under Community competition law only if it has infringed prohibitions contained in Articles 85(1) and $86 \ldots .$. It follows that the aim of [Article 85(1)] is not to eliminate obstacles to intra-Community trade altogether; it is more limited, since

29. Regulation 1/58, JO 1958, 385, Art. 3.

30. Cement judgment, supra n.21, para. 643 .

31. Cases T-31, 38, 45, 46, 51, 53, 56, 57 \& 64/95.

32. Cases C-204 etc/00P Aalborg Portland and ors v. Commission, pending.

33. Cases T-31 \& 32/95.

34. Case T-2/01 Verenigd Nederlandse Cementindustrie v. Commission and Case T-3/01

Eerste Nederlandse Cement Industrie v. Commission, both pending.

35. 47 I.C.L.Q. 713, 715.

36. Decision 96/478 (Bayer/Adalat) OJ 1996 L201/1.

37. Case T-41/96 Bayer v. Commission, judgment of 26 Oct. 2000, not yet reported. 
only obstacles to competition set up [mis en place; geschaffen] as a result of concurrence of wills between at least two parties are prohibited by that provision .... [T] he right of a manufacturer ... to adopt a solution which seems to him to be the best is qualified by the Treaty provisions on competition only to the extent that he must comply with the prohibitions referred to in Articles 85 and 86. Accordingly, provided he does so without abusing a dominant position, and there is no concurrence of wills between him and his wholesalers, a manufacturer may adopt the supply policy which he considers necessary, even if, by the very nature of its aim, for example, to hinder parallel imports, the implementation of that policy may entail restrictions on competition and affect trade between Member States. ${ }^{38}$

So the Commission may not impugn a course of commercial conduct simply because it distorts competition; it must be conduct which is proscribed.

Elements of Bayer may be identified in Volkswagen, in which the Commission found Volkswagen to have imposed upon its Italian dealers an export ban by virtue of a series of preventive and monitoring measures and threat of sanctions given effect by circulars and word of mouth designed to sustain higher prices in the German and Austrian markets, and imposed a fine of $€ 102$ million $^{39}$ - the highest fine ever visited upon a single undertaking. Volkswagen, not surprisingly, challenged the decision under Article 230. The Court of First Instance has now annulled the decision on two minor particulars (the existence of a system for splitting margins and miscalculation of the duration of the infringement) and so reduced the fine to $€ 90$ million, but otherwise upheld the Commission. ${ }^{40}$ The Court confirmed that Volkswagen's conduct was not a unilateral act but "an agreement within the meaning of [Article 81(1)] if it forms part of a set of continuous business relations governed by a general agreement drawn up in advance" ${ }^{41}$ So the test was met here, but not in Bayer.

In any event, the Commission refuses to stay down, and is determined to test the limits of Article 81(1). It has returned to the fray with a fresh decision involving Opel Nederland BV, the Dutch General Motors subsidiary, which is similar to Volkswagen but with traces of Bayer $;{ }^{42}$ even the Commission admits that Opel's strategy "was not in itself agreed between the importer [Opel] and the dealers", ${ }^{43}$ yet nevertheless libels the existence of an agreement because that strategy "became an integral part of the dealer contract" ${ }^{44}$ and "form[s] part of the contractual relationships which Opel Nederland BV maintained with its dealers" ${ }^{45}$ In the meanwhile, Volkswagen has appealed, ${ }^{46}$ in part on the ground that its "restriction of supply" to the Italian market was a unilateral act, and the Commission has appealed in Bayer, ${ }^{47}$ essentially on grounds of "excessively restrictive" and erroneous interpretation of the concept of an agreement within the meaning of Article 81(1). This one could run and run.

38. Ibid, paras 174,176 .

39. Decision 98/273 (Volkswagen) OJ 1998 L124/60.

40. Case T-62/98 Volkswagen v. Commission, judgment of 6 July 2000, not yet reported.

41. Ibid, para. 236 .

42. Decision 2001/146 (Opel) OJ 2001 L59/1.

43. Ibid, para. 103

44. Idem.

45. Ibid, para. 111 .

46. Case C-338/00P Volkswagen v. Commission, pending.

47. Case C-3/01P Commission v. Bayer, pending. 


\section{B. Block Exemption}

There has been very substantial change to the scheme of block exemptions giving effect to Article 81(3), whereby categories of agreements, decisions of associations of undertakings and concerted practices which meet certain prescribed criteria are automatically exempted from the prohibition of Article 81(1). Following on from the 1997 Green Paper on vertical restraints ${ }^{48}$ and the 1998 "follow-up paper" to it ${ }^{49}$ which recommended the adoption of a more "economics-based" approach to the exemption of restraints in vertical agreements, in 1999 the Council made substantial amendments to Regulation $19,{ }^{50}$ the general enabling regulation for block exemptions, giving the Commission a much freer hand in the area. In December 1999 the Commission adopted a new block exemption on vertical restraints ${ }^{51}$ which replaced the previous block exemptions on exclusive distribution, ${ }^{52}$ exclusive purchasing ${ }^{53}$ and franchising ${ }^{54}$ and came into force in June $2000 .{ }^{55}$ It applies to

agreements or concerted practices entered into between two or more undertakings each of which operates, for the purposes of the agreement, at a different level of the production or distribution chain, and relating to the conditions under which the parties may purchase, sell or resell certain goods or services ("vertical agreements")

except those involving (a) a supplier or a buyer which enjoys a market share exceeding 30 per cent of the relevant market, ${ }^{57}$ (b) an association of distributors with a combined annual turnover exceeding $€ 50$ million $^{58}$ and (c) competing undertakings (entering into a non-reciprocal vertical agreement) where the buyer is a manufacturer (and not merely a distributor) with an annual turnover exceeding $€ 100$ million. ${ }^{59}$ The Regulation provides a black list excluding certain hardcore restraints, principally the imposition of fixed or minimum resale prices ${ }^{60}$ certain resale conditions and forms of territorial protection (including passive (but not active) sales outwith the contract territory), ${ }^{61}$ "non-compete" clauses except of short duration, ${ }^{62}$ restraints following termination of the agreement ${ }^{63}$ and certain sales restrictions within a selective distribution system, ${ }^{64}$ but sets out no white list. The Commission and-a new device made possible only with the 1999 amendments to Regulation 19-national competition authorities which can show

48. Green Paper on Vertical Restraints in EC Competition Policy, COM (96) 721 fin.

49. Follow-Up to the Green Paper on vertical restraints: Communication on the Application of the Community competition rules to vertical restraints, OJ 1998 C365/3.

50. Regulation 1215/1999 OJ 1999 L148/1, amending Regulation 19/65 JO 1965, 533.

51. Regulation 2790/1999 OJ 1999 L336/21.

52. Regulation 1983/83 OJ 1983 L173/1.

53. Regulation 1984/83 OJ 1983 L173/5.

54. Regulation 4087/88 OJ 1988 L359/46.

55. Regulation 2790/1999, Art. 13.

56. Art. 2(1).

57. Art. 3.

58. Art. 2(2).

59. Art. 1(4).

60. Art. 4(a)

61. Art. 4(b), (c).

62. Art. 5(a)

63. Art. 5(b).

64. Arts 4(c), (d) and 5(c). 
within their territory the characteristics of a distinct geographic market may withdraw the benefits of exemption in a particular case where a vertical agreement falling within the regulation nevertheless produces effects incompatible with Article 81(3). ${ }^{65}$ The Commission may do so with blanket effect, by regulation and without showing incompatibility with Article 81(3), where parallel networks of similar vertical restraints cover more than 50 per cent of a relevant market. ${ }^{66}$ The new Regulation, says the Commission, creates a "safe harbour" for vertical agreements, ${ }^{67}$ especially for parties which are small and medium sized undertakings, and allows for a greater degree of suppleness, lessening the "straightjacket" effect of previous block exemptions, without sacrificing legal certainty. ${ }^{68}$ A notice providing guidelines on its application has now been issued by the Commission. ${ }^{69}$ The regulation is accorded a life span of 10 years. ${ }^{70}$

In Spring 2000 the block exemption on liner shipping consortia was replaced with immediate effect and valid for a period of five years. ${ }^{71}$ In late 2000 the block exemptions on specialisation agreements and on research and development agreements were replaced with effect from 1 January $2001 .^{72}$ Both emulate (but to a lesser degree) the economics-based approach of the new vertical restraints block exemption by providing market share thresholds. ${ }^{73}$ Equally they both provide black list but no white list criteria. They were subsequently supplemented ("complemented") by a Commission notice providing (fairly extensive) guidelines on the applicability of Article 81 to horizontal co-operation agreements. ${ }^{74}$ They are valid until the end of $2010 .^{75}$ Also in late 2000 the Commission published an evaluation report on the 1995 block exemption regulation for motor vehicle distribution ${ }^{76}$ which was uncommonly critical of its achievements, and suggests that should it be renewed when it comes up for expiry in mid-2002, it will be significantly amended. Further reports and hearings are underway. ${ }^{77}$ In March 2001 the Commission put in train a review of the 1996 technology transfer block exemption. $^{78}$

65. Arts 6,7.

66. Art. 8.

67. Guidelines on vertical restraints attached to the draft regulation, OJ 1999 C270/7, Chap. III 1.

68. Proposal for a Council Regulation amending Regulation 19/65, COM(98) 546 fin, Explanatory Memorandum.

69. OJ 2000 C291/1.

70. Regulation 2790/1999, Art. 13.

71. Regulation 823/2000 OJ 2000 L100/24, replacing Regulation 479/92 OJ 1992 L55/3; entry into force and expiry of Regulation 823/2000 provided in Art. 14.

72. Regulation 2658/2000 OJ 2000 L304/3 (the "specialisation block exemption regulation", replacing Regulation 417/85 OJ 1985 L53/1) and Regulation 2659/2000 OJ 2000 L304/7 (the "R \& D block exemption regulation", replacing Regulation 418/85 OJ 1985 L53/5).

73. Regulation 2658/2000, Art. 4; Regulation 2659/2000, Art. 4(2-3).

74. OJ $2001 \mathrm{C} 3 / 2$.

75. Regulation 2658/2000, Art. 9; Regulation 2659/2000, Art. 9.

76. Report on the evaluation of Regulation (EC) No 1475/95 on the application of Art. 85(3) of the Treaty to certain categories of motor vehicle distribution and servicing agreements, $\operatorname{COM}(2000) 743$ fin.

77. See Commission press release IP/01/204.

78. Regulation 240/96 OJ 1996 L31/2; see Art. 12(2). 
Block exemptions were also introduced for the first time in the field of State aids. Using powers granted by the Council in $1998^{79}$ - the first legislation to be adopted by the Treaty authority of Article 89-in January 2001 the Commission adopted three block exemptions regulations, on training aid, ${ }^{80}$ de minimis aid ${ }^{81}$ and aid to small and medium sized enterprises (sic) ${ }^{82}$ Aid granted by the authorities of a Member State falling within the block exemptions is, without need for notification to the Commission (in accordance with the 1999 State aids supervisory regulation ${ }^{83}$ ), compatible with the common market within the meaning of Article 87(3) of the Treaty-that is, it is automatically exempted from the prohibition of unfair State aids in Article 87(1). The training aid block exemption embraces individual aids and aid schemes for specific training and general training of varying degrees of gross aid intensity depending upon the size of the subvented undertaking and its eligibility for regional aid $^{84}$ up to a ceiling of $€ 1$ million for a single training project for a single undertaking. ${ }^{85}$ The de minimis block exemption is of general application and exempts aid granted to any single undertaking of up to $€ 100,000$ over any three year period. It is a particularly useful development because, unlike the prohibition of Article 81(1), the Court of Justice has never recognised a de minimis exception to Article 87(1). The SME block exemption exempts, in varying degrees of aid intensity, investment aid and consultancy aid to SMEs (as defined by Community law ${ }^{86}$ ) up to a ceiling of $€ 15$ million total gross aid on a project costing no more than $€ 25$ million. ${ }^{87}$ Both the training and the SME block exemptions require to be cited in any aid package as a condition of their application. ${ }^{88}$ The de minimis block exemption does not apply in the transport or agricultural sectors, ${ }^{89}$ the SME block exemption excludes agricultural production or processing,$^{90}$ which is expressly saved under the training block exemption. ${ }^{91}$ In order to comply with the WTO agreement on subsidies and countervailing measures the de minimis and SME block exemptions exclude export aids and aid favouring domestic over imported goods. ${ }^{92}$ All three require Member States carefully to keep books for purposes of transparency and monitoring. ${ }^{93}$ Unlike block exemptions generally they contain no provision for

79. Regulation 994/98 OJ 1998 L142/1.

80. Regulation 68/2001 OJ 2001 L10/20.

81. Regulation 69/2001 OJ 2001 L10/30.

82. Regulation 70/2001 OJ $2001 \mathrm{~L} 10 / 33$.

83. Regulation 659/99 OJ 1999 L83/1.

84. Regulation 68/2001, Art. 4.

85. Art. 5.

86. Commission Recommendation 96/280 OJ 1996 L107/4. Small undertakings are those with fewer than 50 employees and either an annual turnover of no more than $€ 7$ million or an annual balance sheet total of no more than $€ 5$ million; medium sized undertakings are larger but with fewer than 250 employees and either an annual turnover of no more than €40 million or an annual balance sheet total of no more than $€ 27$ million.

87. Regulation 70/2001, Arts 4-6.

88. Regulation 68/2001, Art. 3(1) and (2)(b); Regulation 70/2001, Art. 3(1) and (2)(b).

89. Regulation 69/2001, Art. 1(a)

90. Regulation 70/2001, Art. 1(2)(a).

91. Regulation 68/2001, Art. 1.

92. Regulation 69/2001, Art. 1(2)(b-c); Regulation 70/2001, Art. 1(2)(b-c).

93. Regulation 68/2001, Art. 7; Regulation 69/2001, Art. 3; Regulation 70/2001, Art. 9. 
the Commission to withdraw their application in a given situation. Each is valid until 2007.94

\section{Oligopolies}

Much of the running on the development of the principles governing joint or collective dominance - that is, situations in which no one undertaking is dominant in a market within the meaning of Article 82 but where such dominance may be said to be shared amongst a small number of undertakings owing to the oligopolistic nature of the market - has been done by the Court of First Instance. With Compagnie Maritime Belge, a case involving a liner conference on appeal from a judgment of the Court of First Instance, ${ }^{95}$ the Court of Justice was afforded the opportunity of imposing its own imprimatur upon the developing case law. Thitherto undertakings were deemed to share a collective dominant position only if there could be found between or amongst them economic links ${ }^{96}$ or simply links which were "sufficiently strong" ${ }^{\text {"97 }}$ such that they adopted the same conduct on the market. In Compagnie Maritime Belge the Court has now decided upon a requirement of economic links or other factors. It is worth citing the judgment at length, for it has the ring of an arrêt de principe:

[T] he expression "one or more undertakings" in Article 86 of the Treaty implies that a dominant position may be held by two or more economic entities legally independent of each other, provided that from an economic point of view they present themselves or act together on a particular market as a collective entity. This is how the expression "collective dominant position" ... should be understood .... In order to establish the existence of a collective entity as defined above, it is necessary to examine the economic links or factors which give rise to a connection between the undertakings concerned.

In particular, it must be ascertained whether economic links exist between the undertakings which enable them to act together independently of their competitors, their customers and consumers....

Nevertheless, the existence of an agreement or other links in law is not indispensable to a finding of collective dominant position; such a finding may be based on other connecting factors and would depend on an economic assessment and, in particular, on an assessment of the structure of the market in question. ${ }^{98}$

This is a new development, for it strongly suggests that "other connecting factors" which depend "in particular, on an assessment of the structure of the market in question" may exist in mere oligopolistic interdependence, or in other words the natural state of an oligopolistic market. If so, it draws a great many undertakings and circumstances within the discipline of Article 82. Whether it is so may require further elaboration from the Court-which may be forthcoming in the appeal in

94. Regulation 68/2001, Art. 8(1); Regulation 69/2001, Art. 4(1); Regulation 70/2001, Art. $10(1)$.

95. Cases T-24 etc/94 Compagnie Maritime Belge and ors v. Commission [1996] E.C.R. II-1201.

96. Cases T-68, 77 \& 78/89 Società Italiano Vetro v. Commission (Flat Glass) [1992] E.C.R. II-1403.

97. Case C-393/92 Gemeente Almelo v. Energiebedrijf IJsselmij [1994] E.C.R. I-1477.

98. Cases C-395 \& 396/96P Compagnie Maritime Belge and ors v. Commission, judgment of 16 March 2000, not yet reported, at paras 36, 41, 42 and 45. 
Irish Sugar $^{99}$ or in review of the Transatlantic Conference Agreement (TACA) decision. ${ }^{100}$

\section{Mergers}

In June 2000 the Commission published a report on the application of the Merger Regulation. $^{101}$ It found that, notwithstanding the "supplementary turnover thresholds" introduced in 1998, there were still a number of cross-border concentrations falling outwith the Regulation. Whilst thus expressing concern, it has as yet made no proposal for change. Two more notices have been published, one laying down an expedited ("simplified") procedure for assessment of certain concentrations notified under the Regulation which pose little threat to competition, ${ }^{102}$ the other providing guidance on the type of modifications to a concentration likely to render it compatible with the common market. ${ }^{103}$ It ought to be noted that Boeing/Hughes, involving as it did a concentration between high profile American undertakings in the field of geostationary communications satellites and so capable of a repeat of the type of rancour generated by the 1997 Boeing/MacDonnell Douglas concentration decision, ${ }^{104}$ went to phase II proceedings but was thereafter approved on the nod. ${ }^{105}$ The number of notifications under the Regulation continues to grow, reaching 292 in 1999 and 345 in 2000; the number of concentrations prohibited has climbed to 14 , with three prohibitions ordered in the period under consideration. ${ }^{106}$ And Denmark has adopted its own merger control legislation, ${ }^{107}$ leaving only Luxembourg without.

\section{(E) Reform of Regulation 17 and Enforcement by National Authorities}

The wholesale reform of Regulation 17 proposed in the 1999 Commission White Paper ${ }^{108}$ was considered in a previous note. ${ }^{109}$ The Commission has now proposed a draft regulation giving effect to the proposals, ${ }^{110}$ and remains fairly faithful to the White Paper. The current Swedish presidency of the Council is said to be enthusiastic, and it is suggested in some quarters that the new legislation will be adopted by the end of its presidency.

99. Case C-497/99P Irish Sugar v. Commission, pending.

100. Cases T-191 etc/98 Atlantic Containers Line and ors v. Commission, pending.

101. COM (2000) 399 fin.

102. OJ $2000 \mathrm{C} 217 / 32$

103. OJ $2001 \mathrm{C} 68 / 3$.

104. Decision $97 / 816$ OJ 1997 L336/16.

105. Case M.1879 (Boeing/Hughes), decision of 27 Sept. 2000, not yet published.

106. Case M.1672 (Volvo/Scania), decision of 15 March 2000; Case M.1741 (MCI

Worldcom/Sprint), decision of 28 June 2000; Case M.2097 (SCA/Metsä Tissue), decision of 31 Jan. 2001; none yet published.

107. Lov nr. 416 af 31. maj 2000 (Lov om ændring af konkurrenceloven); Konkurrenceloven, $\S \S 12-12 \mathrm{~g}$; in force 1 Oct. 2000.

108. White Paper on Modernisation of the Rules Implementing Articles 85 and 86 of the EC Treaty, OJ 1999 C132/1.

109. 49 I.C.L.Q. 227, 231-234.

110. Proposal for a Council Regulation on the implementation of the rules on competition laid down in Arts 81 and 82 of the Treaty, OJ 2000 C365E/284. 
The White Paper and the draft regulation envisage not only the enforcement of Article $81(3)$ by national courts but also the vigorous enforcement by national administrative authorities of the entirety of Articles 81 and 82. Denmark adopted legislation providing the statutory authority and procedures necessary to enable the Konkurrenceråd to do so. ${ }^{111}$ The six Member States which have not yet taken this step (Ireland, Luxembourg, Austria, Finland, Sweden and the United Kingdom) will be obliged to do so if the draft regulation is adopted, within a time period yet to be set. ${ }^{112}$

The Court of Justice has also supplied guidance on the duties of national courts faced with mutually incompatible orders from the Commission and national courts. In 1990 an Irish manufacturer (Masterfoods) sought a declaration from the High Court that a competitor was infringing both Articles 81 and 82 in the Irish ice cream market. It also lodged a complaint with the Commission under Regulation 17. In 1992 the High Court found for the competitor and pronounced a permanent injunction restraining Masterfoods from (tortious) interference with the former's contractual rights. ${ }^{113}$ But in due season (six years later) the Commission came to the opposite conclusion, finding and ordering termination of infringments of Articles 81 and $82 .{ }^{114}$ The competitor immediately raised annulment proceedings before the Court of First Instance. ${ }^{115}$ But in the meanwhile the original High Court injunction was appealed to the Supreme Court, which looked to Luxembourg for advice as to the proper course to follow. The Court of Justice has now responded, ${ }^{116}$ and in the interests of uniform application of Community law, grants precedence to the Commission:

[W] here a national court is ruling on an agreement or practice the compatibility of which with [sic] Articles 85(1) and 86 of the Treaty is already the subject of the Commission decision, it cannot take a decision running counter to that of the Commission, even if the latter's decision conflicts with a decision given by a national court of first instance. ${ }^{117}$

Since the Court of Justice alone has jurisdiction to impugn a Commission decision, ${ }^{118}$ the only option available to the national court is to refer a question of validity to the Court of Justice (if the addressee of the decision or an interested party has not already raised an action of annulment before the Court of First Instance) and stay proceedings pending judgment from Luxembourg. ${ }^{119}$ But this is hardly satisfactory. It is an exercise in three-tier judicial geometry. There is no indication of why (or if) it should be presumed that the Commission is more likely than the national court to have supplied the correct answer to the issue-and in this case we still do not know the correct answer: for that we are waiting upon the

111. Lov nr. 416 af 31. maj 2000, supra n.107; Konkurrenceloven, $\S 23 a$; in force 1 Oct. 2000.

112. Draft regulation, supra n.110, Art. 36.

113. HB Ice Cream v. Masterfoods, unreported order of the High Court, 28 May 1982.

114. Decision 98/531 (van den Bergh Foods) OJ 1998 L246/1.

115. Case T-65/98 van den Bergh Foods v. Commission, pending.

116. Case C-344/98 Masterfoods v. HB Ice Cream, judgment of 14 Dec. 2000, not yet reported.

117. Ibid, para. 60 .

118. Case 314/85 Foto-Frost v. Hauptzollamt Lübeck-Ost [1987] E.C.R. 4199.

119. Case C-344/98 Masterfoods, supra n.116, at paras 57, 60. 
Court of First Instance, which itself stayed proceedings waiting upon the judgment of the Court of Justice. ${ }^{120}$ Bearing in mind this is a minor ice cream donnybrook which started in 1989 and is still not resolved, none of this augurs well for the European Convention requirement of access to speedy justice. It may also kick start a new generation of important litigation should the Court of First Instance (and doubtless the Court of Justice on appeal) find for Masterfoods, and should Masterfoods then seek damages (which in Irish law can be exemplary ${ }^{121}$ ) from its competitor (for prosecuting a course of conduct which was ordered by a national court). The problem will only become more commonplace if the draft regulation is adopted and national courts and administrative authorities come to apply the panoply of Articles 81 and 82. The White Paper solution to this was Commission intervention to override a definitive judgment of a national court but subject to res judicata applying to the dispute between the parties; ${ }^{122}$ but here the draft regulation is silent.

It ought finally to be noted that the Competition Act 1998 came into force in the United Kingdom in March 2000. Following the initiatives of a number of other Member States, the Act incorporates wholesale into U.K. law the scheme and methods of EC competition law. Indeed section 2 ("the Chapter I prohibition") and section 18 ("the Chapter II prohibition") are effectively verbatim copies of Articles 81(1) and 82. So "Community friendly" is the Act that agreements enjoying exemption, by virtue of either individual or block exemption, from Article 81(1) are automatically exempted from the Chapter I prohibition ("parallel exemption"). ${ }^{123}$ There is also provision (the so-called "Europrinciples clause") that the Act be interpreted and applied "so far as is possible" in a manner consistent "with the treatment of corresponding questions arising in Community law in relation to competition within the Community". ${ }^{124}$ This statutory direction binds both the courts and the administrative authorities competent to enforce the Act, and applies to the principles laid down by the Treaty and by the Court of Justice, any relevant decision of the Court and any relevant decision or statement of the Commission. ${ }^{125}$ In terms of fealty to and likely harmony with Community law, the Commission could not ask for more. The irony is that the Act voluntarily subsumes purely U.K. law to the development of Community law (and this from the Member State with the most vocal complaints of Community interference in national affairs) and mimics the Regulation 17 system of prohibition/ex post

120. Case T-65/98R van den Bergh Foods v. Commission, unreported order of 28 April 1999.

121. Competition Act, 1991 (Act No. 24 of 1991), Section 6(3)(b). Because exemplary damages are available under the Competition Act, that remedy must also be available for infringement of Arts 81 and 82; applying Cases C-46 \& 48/93 Brasserie du Pêcheur v. Germany and $R$ v. Secretary of State for Transport, ex parte Factortame [1996] E.C.R. I-1029. 122. White Paper, para. 102(ii).

123. Section 10. This device is also recognised in Belgian (loi du 5 août 1991, article 32), Danish (Konkurrenceloven, § 4), Spanish (Real decreto 157/1992 de 2 de feb. de 1992, articulo 11) and Dutch (Mededingingswet, Artikelen 12,14) law. It is a requirement of the White Paper proposals (para 85) and implicit in the draft regulation, Art. 3.

124. Section 60(1).

125. Section 60(2-4) 
administrative exemption at just the time the Community appears to be abandoning it.

ROBERT LANE*

* Senior Lecturer in Law, University of Edinburgh. 